\title{
Predicting Field Generations of The Green Peach Aphid, Myzus persicae (Sulzer) and Its Predator, Green Lace-Wing, Chrysoperla carnea (Stephens) by Using Heat Units Accumulation and Evaluation of Some Insecticides against Their Populations
}

\author{
Adnan Abdel-Fattah El-Sayed Darwish, Mohammed Mabrouk Ragab Attia \\ Plant Protection Department, Faculty of Agriculture, Damanhour University, Egypt
}

\begin{abstract}
Applying a precise forecasting method is necessary to achieve acceptable results in integrated pest management programs. The objectives of this work were to predict the occurrence of population of Myzus persicae (Hemiptera: Aphididae) and Chrysoperla carnea (Neuroptera: Chrysopidae), determine the influence of temperature and relative humidity on their population densities and also to study the effect of five insecticides on the population of these insect species in potato plants under field conditions at Nobaria district, El-Beheira Governorate, Egypt. The populations of M. persicae and C. carnea were monitored on potato plants from February to May of 2015 and 2016 seasons. The population peaks of these insects were predicted using a degree-day model (accumulated thermal units). The obtained results revealed that the green peach aphid has nine field generations while the green lace-wing has two field generations. The general average of deviations between the expected peaks compared to the observed peaks were -1.333 and -1 days in case of $M$. persicae, while these averages were +3 and -1 days in case of green lace-wing in 2015 and 2016 seasons, respectively. The effect of the meteorological factors such as temperature and relative humidity on population of these insect were studied. The correlation results revealed that the incidence of $M$. persicae and $C$. carnea were significantly and positively correlated in descending order with minimum, mean, and maximum temperature degree, respectively. The efficiency of acetamiprid, thiamethoxam, pymetrozine, chlorantraniliprole and pirimicarb on $M$. persicae and C. carnea populations was determined. These insecticides could be arranged in ascending order as: acetamiprid $>$ thiamethoxam $>$ chlorantraniliprole $>$ pymetrozine $>$ pirimicarb for controlling the green peach aphid. While regarding their harmful effect on the $C$. carnea population their order became chlorantraniliprole $>$ pirimicarb $>$ thiamethoxam $>$ acetamiprid $>$ pymetrozine. These results were repeated in both seasons of study, 2015 and 2016.
\end{abstract}

Key words: Myzus persicae, Chrysoperla carnea, degree-day model, insecticides, potato plants.

\section{INTRODUCTION}

Potato plants have been attacked by green peach aphid, Myzus persicae which causing substantial loss to potato crop (Saljoqi, 2009). The green peach aphid, $M$. persicae is a generalist species infesting more than 400 plant species (Francis et al., 2006) and considered to be a major pest of potatoes worldwide (Raman and Midmore, 1983). The green peach aphid has a complex life cycle with 10 to 25 generations a year. Most generations consist of parthenogenetic females that produce live nymphs without mating. The population spreads from one host to another all year round as new hosts become available (Western Regional IPM project, 2006). Larvae of green lacewing, Chrysoperla carnea are active predators, feed on many soft-bodied insects, mainly aphids. It is considered one of the most important predators of M. persicae and has a wide range of habitats (Henn and Weinzer, 1990 and Abd El-Hameed Neama et $a l ., 2016)$. For an efficient control of aphids or any other insect, it is necessary to determine the right timing of attack in relation to weather factors, which may enable the prediction of insect occurrence (Chattopadhyay et al., 2005). The main environmental variables acting on aphids, associated to the occurrence of population peaks are the meteorological factors, especially temperature (Dixon, 1998; Tang et al., 1999; Asin \& Pons, 2001). Several authors have predicted aphid occurrence by meteorological factors (Chattopadhyay et al., 2005; Zamani et al., 2006 and Klueken et al., 2009). The using of the accumulated thermal heat units (degree-days, DD's) allows for predicting pest occurrence and helpful in monitoring pest activity, therefore can be considered an aid tool for scheduling sprays and biocontrol agent releases at the optimum time. The occurrence of many insect species had been predicted by Degree day models, such as that of the pink bollworm, Pectinophora gossypiella (Saund.) (Yones, et al., 2012), the date palm scale, Parlatoria blanchardii (Salman, et al., 2016) and aphids (Hanula et al., 2002; Chakravarty and Gautam, 2004; Gomez et al., 2009; Cividanes and SantosCividanes, 2012; Tabikha, 2016), helping in the 
programs of integrated pest management. The current integrated pest management programs for many insect pests are dominated by the use of insecticides that typically rely on sampling, threshold and resistance information to optimize timing of applications and make best use of existing chemistry (Palumbo et al., 2001). Some commonly used insecticides may only worsen an aphid outbreak by removing aphid predator species and allowing the population to dramatical increase. In recent years, selective insecticides were introduced into the market instead of traditional insecticides because of insect pests (such as aphids) became more resistant to the most conventional insecticides (Tomizawa et al., 2007).

The objectives of this work were to predict the generation peaks of $M$. persicae and its predator, green lace-wing, C. carnea in the field using the relationship between population fluctuation of these insects and degree-days (DD's), to determine the influence of weather factors on their population density and also to study the effect of five insecticides on the population of these insects under field conditions at Nobaria district, El-Beheira Governorate, Egypt during seasons of 2015 and 2016.

\section{MATERIALS AND METHODS}

The present study was conducted in spring potato crop (Kara cultivar), sown on 2015 and 2016 seasons at private farm (an area of about one feddan; feddan $=4200 \mathrm{~m}^{2}$ ) in Nobaria district, Egypt. Potato tubers were planted on January $23^{\text {rd }}$ in the $1^{\text {st }}$ season and Jan. $14^{\text {th }}$ in the $2^{\text {nd }}$ season at an inter-row distance of $75 \mathrm{~cm}$ and an intra-row distance of $25 \mathrm{~cm}$. All the necessary cultural practices were adopted throughout the growing season according to recommendation. However, spray of any kind of insecticide was avoided in the experimental area.

Population density of green peach aphids, $M$. persicae

Samples of thirty leaves, three leaves from each plant, one leaf from the top, middle and lower regions of ten randomly selected plants (avoiding the border rows) were collected and examined every three days to estimate $M$. persicae population. Sampling started with the first colonization of $M$. persicae on potato plants and continued until the crop harvest.

Population density green lace-wing, $C$. carnea

For the estimation of $C$. carnea population, ten plants were selected randomly and the whole population of $C$. carnea larvae was counted carefully at three day intervals after about one month of sowing till harvest of the crop. During both seasons, the counted $M$. persicae and its predators were presented graphically to determine the population peaks in the successive generations in relation to the accumulated thermal units in degree-days.

Predicting $M$. persicae and $C$. carnea generation peaks using thermal units accumulations

The occurrence of population peaks was predicted using a degree-day model, according to Silveira Neto et al. (1976). This model requires the lower developmental thermal threshold ( $\mathrm{Tb}$ ) and the maximum and minimum temperatures of the environment to calculate the number of degree-days. The lower developmental thermal threshold ( $\mathrm{Tb}$ ) and thermal requirements for $M$. persicae were estimated by $\mathrm{Tb}=2.23^{\circ} \mathrm{C}$ and $\mathrm{K}=165.6$ degree-day (Cividanes \& Souza, 2003), while these values for C. carnea were $\mathrm{Tb}=10.2^{\circ} \mathrm{C}$ and $\mathrm{K}=414$ degreedays (Fujiwara and Nomura, 1999). The counting of degree-days by the model was started on the date of the first appearance of the insects on the leaf samples. Daily maximum and minimum temperatures were obtained and recorded by Central Laboratory for Agricultural Climate (CLAC).

The following formula was used for computing the degree-days (dd's) according to Richmond et al., (1983) under fluctuating temperatures:

$\mathrm{H}=\Sigma \mathrm{HJ}$

Where:

$\mathrm{H}=$ number of heat units (number of degree-day units);

$\mathrm{HJ}=[(\max .+\min ) / 2]-.\mathrm{C}$, if $\max .>\mathrm{C} \& \min .>\mathrm{C}$.

$=(\max .-\mathrm{C}) 2 /(\max .-\min )$, if $\max .>\mathrm{C} \& \min <\mathrm{C}$.

$=0$, if $\max .<\mathrm{C} \& \min .<\mathrm{C}$.

$\mathrm{C}=$ threshold temperature.

Effect of climatic factors:

The considered and dominating meteorological factors during the investigation period were daily mean max. temperature, daily mean min. temp., daily mean temp., daily mean max. R. H. \%, daily mean min. R. H. \% and daily mean R. H. \%). The simple correlation between the selected environmental factors and the population density of $M$. persicae and $C$. carnea were calculated. Statistical analysis of the present results was achieved according to the methods of Steal and Torrie (1960).

Effect of five insecticides on the population of $\boldsymbol{M}$. persicae and its predator $C$. carnea:

Five insecticides were evaluated against $M$. persicae and $C$. carnea populations on potato plants. An area of about $1200 \mathrm{~m}^{2}$ was divided into 24 plots, of $50 \mathrm{~m}^{2}$ each. Every 4 plots were considered for each applied treatment in addition to the 4 control plots. Applications of the five treatments were in April in the two seasons. Ten leaves from each plot were examined and the number of alive individuals of $M$. persicae were counted before treatment and after 1, 4, 7 and 14 days of the treatment. Concerning $C$. carnea ten plants were randomly selected from each plot to be examined and the numbers of alive larvae of $C$. carnea were recorded 
before treatment and after 1, 4, 7 and 14 days from the treatment date. The percentages of population reduction was calculated according the equation of Henderson and Tilton (1955) as following:

$$
\% \text { Reduction }=100 \times 1-\frac{\mathrm{Ta} \times \mathrm{Cb}}{\mathrm{Tb} \times \mathrm{Ca}}
$$

Where:

$\mathrm{Cb}=\mathrm{n}$ in control before application

$\mathrm{Ta}=\mathrm{n}$ in Treatment after application

$\mathrm{Ca}=\mathrm{n}$ in control after application

$\mathrm{Tb}=\mathrm{n}$ in Treatment before application

The tested insecticides were

Chlorantraniliprole (Coragen $20 \% \quad$ SC) provided by DuPont Du Nemours Company at 0.5 $\mathrm{ml} \mathrm{L}{ }^{-1}$.

Pirimicarb (Aphox 50\% DG) provided by Syngenta Company at $30 \mathrm{mg} \mathrm{L}^{-1}$.

Thiamethoxam (Actara 25\% WG) provided by Syngenta Company at $50 \mathrm{mg} \mathrm{L}^{-1}$.

Pymetrozine (chess 25\% WP) provided by Syngenta Company at $500 \mathrm{mg} \mathrm{L}^{-1}$.

Acetamiprid (Mospilan 20\% SP) provided by Nippon Soda Ltd at $25 \mathrm{mg} \mathrm{L}^{-1}$.

Data analysis: Statistically significant mean values $(P<0.05)$ were calculated as mean $\pm \mathrm{SD}$ (standard deviation) using analysis of variance (ANOVA) and separated by LSD test (SAS Statistical software, 1999).

\section{RESULTS AND DISCUSSION}

The first appearance of $M$. persicae on potato plants was observed on February $19^{\text {th }}(0.367$ individuals/ leaf) and February $22^{\text {nd }}$ (0.4 individuals/ leaf) in 2015 and 2016, respectively. While the $1^{\text {st }}$ appearance of $C$. carnea was recorded on February $22^{\text {nd }}(0.4$ individual/ plant $)$ and February $13^{\text {th }}(0.1$ individual/ plant) in 2015 and 2016 seasons, respectively. With the growing season, the population of these insects increased to the end of harvesting time producing slightly and/or sharply fluctuates to indicate the presence of activity periods. These biofix dates (dates of $1^{\text {st }}$ appearance) were used to start calculate the degree-day model (Cividanes and Santos-Cividanes, 2012) and consequently predict the occurrence of these insects.

Data presented in Tables (1-4) depicted the observed and expected peaks (generations) of $M$. persicae and its predator green lace-wing, C. carnea for 2015 and 2016 seasons.

Green peach aphid, Myzus persicae:

During the $1^{\text {st }}$ season 2015, the observed population peaks of green peach aphid were occurred on $28^{\text {th }}$ of February; March $12^{\text {th }}$ and $21^{\text {st }}$; April $2^{\text {nd }}, 11^{\text {th }}, 20^{\text {th }}$, and $29^{\text {th }}$; and May $8^{\text {th }}$ and $17^{\text {th }}$ where the average of individuals reached 1.167, $2.067,3.433,4.8,6.5,6.433,7.7,5.967$ and 5.33 aphid / leaf, respectively. The expected dates of these generations were March $2^{\text {nd }}$, March $14^{\text {th }}$, March $24^{\text {th }}$, April $3^{\text {rd }}$, April $13^{\text {th }}$, April $21^{\text {st }}$, April $29^{\text {th }}$, May $5^{\text {th }}$ and May $14^{\text {th }}$ with the averages of $163.74,162.24,173.2,172.2,173.2,172.16,164.66$, 174.39 and 156.16 dd's, respectively. The deviations between observed and expected peaks were $-2,-2,-3,-1,-2,-1,0,+2$ and +3 days, respectively, during the year, 2015.

The actual peaks in the $2^{\text {nd }}$ season, 2016 occurred on February $22^{\text {nd }}$; March $3^{\text {rd }}, 12^{\text {th }}$, and $21^{\text {st }}$; April $2^{\text {nd }}, 11^{\text {th }}, 20^{\text {th }}$ and $29^{\text {th }}$ and May $8^{\text {th }}$ where the average of aphid individuals reached 1.267, 1.533, $2.267,2.5,3.833,6.2,6.467,8$ and 5.967 aphid/ leaf, respectively. The expected peaks for this season were on February $22^{\text {nd }}$, March $4^{\text {th }}$, March $14^{\text {th }}$, March $24^{\text {th }}$, April $3^{\text {rd }}$, April $12^{\text {th }}$, April $21^{\text {st }}$, April $29^{\text {th }}$ and May $8^{\text {th }}$ with the degree-day averages of $163.2,172.47,160.2,157.7,158.2,170.93$, 171.93. 169.66 and 174.43 dd's with $0,-1,-2,-3,-1$, $-1,-1,0$ and 0 days as a deviation intervals between the observed and expected peaks, respectively.

Table 1: Comparison between the actually observed and the expected peaks of $M$. persicae generations on potato crop and accumulated thermal units under field conditions at Beheira Governorate

\begin{tabular}{|c|c|c|c|c|c|}
\hline \multirow[t]{2}{*}{ Generation No. } & \multicolumn{2}{|c|}{ Generation date } & \multirow{2}{*}{$\begin{array}{l}\text { Deviation } \\
\text { (days) }\end{array}$} & \multirow{2}{*}{$\begin{array}{l}\text { Mean number of } \\
\text { insets/ leaf }\end{array}$} & \multirow{2}{*}{$\begin{array}{c}\text { Accumulated degree- } \\
\text { days (DD's) }\end{array}$} \\
\hline & Observed & Expected & & & \\
\hline $1 \mathrm{st}$ & $28 / 2$ & $2 / 3$ & -2 & 1.0667 & 163.74 \\
\hline 2nd & $12 / 3$ & $14 / 3$ & -2 & 2.067 & 162.24 \\
\hline $3 \mathrm{rd}$ & $21 / 3$ & $24 / 3$ & -3 & 3.433 & 173.2 \\
\hline 4th & $2 / 4$ & $3 / 4$ & -1 & 4.8 & 172.2 \\
\hline 5 th & $11 / 4$ & $13 / 4$ & -2 & 6.5 & 173.2 \\
\hline 6th & $20 / 4$ & $21 / 4$ & -1 & 6.433 & 172.16 \\
\hline 7 th & $29 / 4$ & $29 / 4$ & 0 & 7.7 & 164.66 \\
\hline 8 th & $8 / 5$ & $6 / 5$ & +2 & 5.967 & 174.39 \\
\hline 9 th & $17 / 5$ & $14 / 5$ & +3 & 5.33 & 156.16 \\
\hline Average & & & -1.333 & & 167.9944 \\
\hline
\end{tabular}
during 2015 season 
Table 2: Comparison between the actually observed and the expected peaks of $M$. persicae generations on potato crop and accumulated thermal units under field conditions at Beheira Governorate during 2016 season

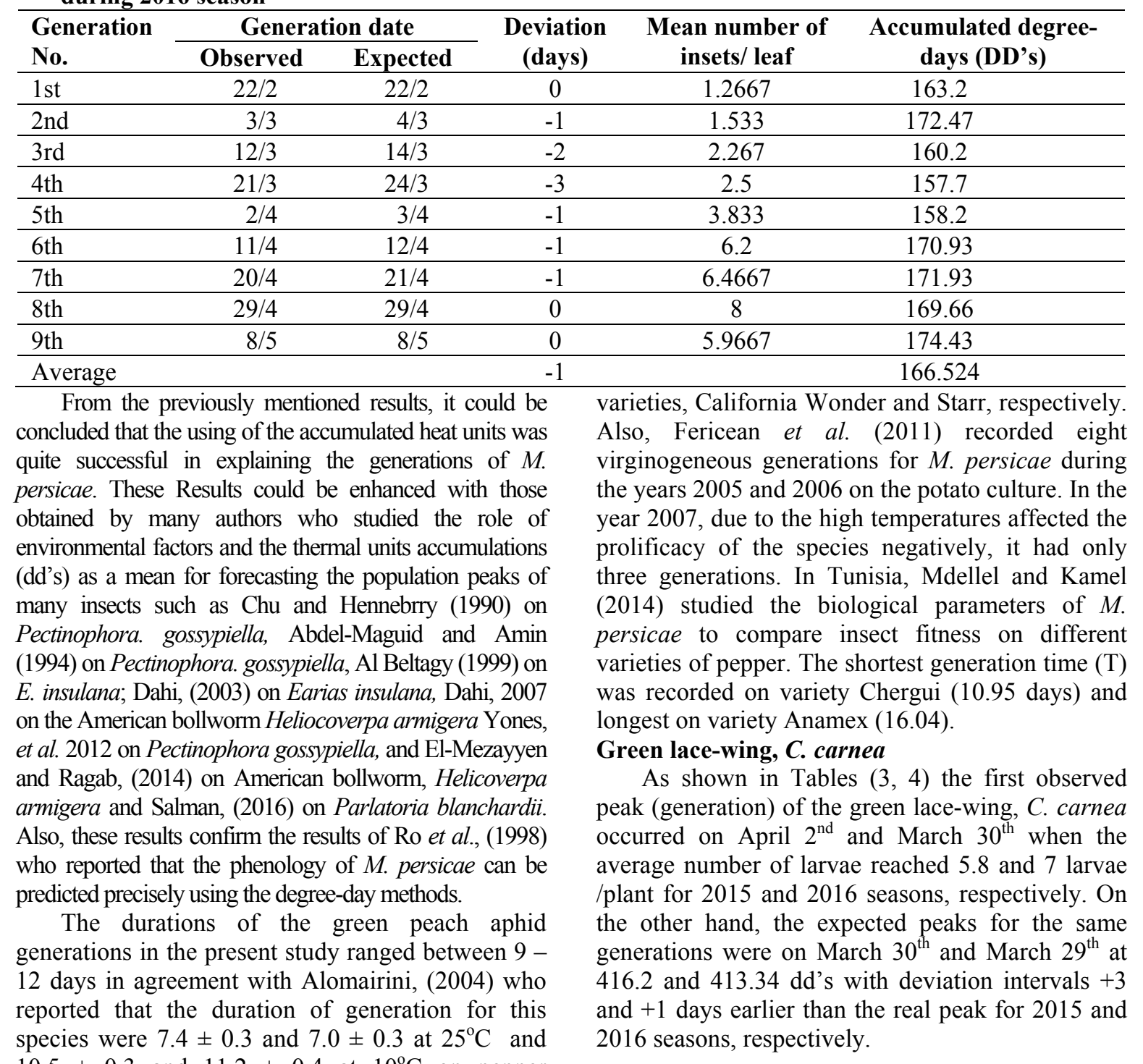
$10.5 \pm 0.3$ and $11.2 \pm 0.4$ at $10^{\circ} \mathrm{C}$ on pepper

Table 3: Comparison between the actually observed and the expected peaks of $C$. carnea generations on potato crop and accumulated thermal units under field conditions in Beheira Governorate during 2015 season

\begin{tabular}{lccccc}
\hline $\begin{array}{l}\text { Generation } \\
\text { No. }\end{array}$ & \multicolumn{2}{c}{ Generation date } & $\begin{array}{c}\text { Deviation } \\
\text { (days) }\end{array}$ & $\begin{array}{c}\text { Mean number of } \\
\text { insects/ plant }\end{array}$ & $\begin{array}{c}\text { Accumulated } \\
\text { degree-days (DD's) }\end{array}$ \\
\hline $1^{\text {st }}$ & $2 / 4$ & $30 / 3$ & +3 & 5.8 & 416.2 \\
$2^{\text {nd }}$ & $5 / 5$ & $2 / 5$ & +3 & 8.1 & 407 \\
\hline Average & & & +3 & & 411.6 \\
\hline
\end{tabular}

Table 4: Comparison between the actually observed and the expected peaks of $C$. carnea generations on potato crop and accumulated thermal units under field conditions in Beheira Governorate during 2016 season

\begin{tabular}{cccccc}
\hline $\begin{array}{c}\text { Generation } \\
\text { No. }\end{array}$ & \multicolumn{2}{c}{ Generation date } & \multirow{2}{\text{Deviation}}{$\begin{array}{c}\text { Mean number of } \\
\text { (days) }\end{array}$} & $\begin{array}{c}\text { Accumulated } \\
\text { insects/ plant }\end{array}$ & $\begin{array}{c}\text { Abserved } \\
\text { degree-days (DD's) }\end{array}$ \\
\cline { 2 - 3 } $1^{\text {st }}$ & $30 / 3$ & $29 / 3$ & +1 & 7 & 413.34 \\
$2^{\text {nd }}$ & $2 / 5$ & $5 / 5$ & -3 & 12.8 & 420.02 \\
Average & & & -1 & & 416.68 \\
\hline
\end{tabular}


The $2^{\text {nd }}$ actual peak occurred on May $5^{\text {th }}$ and May $2^{\text {nd }}$ when the average of larvae per plant reached 8.1 and 12.8 larvae/plant for 2015 and 2016 seasons, respectively. The expected dates of this generation were May $2^{\text {nd }}$ and May $5^{\text {th }}$ with the averages of 407.005 and 420.02 dd's for 2015 and 2016, respectively. The deviation between observed and expected peaks was +3 days earlier for 2015 season and three days later in 2016 season.

Correlation coefficient (r) between mean number of M. persicae and C. carnea and different environmental factors have been evaluated and presented in Table 5. The correlation values showed that environmental factors correlated either positively or negatively with $M$. persicae and $C$. carnea counts. The most important environmental factor closely related to the activity of these insects was the temperature. The maximum, mean and minimum temperature degree positively (high significantly) correlated with populations of $M$. persicae and $C$. carnea (the activity of the insect population correlated positively with temperature) throughout the two seasons of study, 2015 and 2016. Relative humidity was the other most important factor closely related to the activity of $M$. persicae and $C$. carnea. The minimum $\mathrm{RH}$ has negative influence on the population build up M. persicae of C. carnea.

Effect of five insecticides on the population density of $M$. persicae and its predator $C$. carnea:

The data shown in Tables $(6 \& 7)$ illustrated the numbers of green peach aphid which were recorded before and after one, four, seven and fourteen days of treatment with five different insecticides. The general means of reduction percentages of $M$. persicae populations caused by acetamiprid, thiamethoxam, chlorantraniliprole, pymetrozine and pirimicarb were $79.55,78.28,71.34,69.88$ and 60.6 $\%$, respectively in 2015 and 82.73, 81.7, 77.28, 74.33 and $66.93 \%$, respectively in 2016 season. Among the different insecticides tested, acetamiprid and thiamethoxam (Neonicotinoids insecticides) gave the lowest number of M. persicae per leaf after $1,4,7$ and 14 days of application as compared to the other insecticides. Highest number of M. persicae per leaf was recorded in pirimicarb treatment. According to Patil and Lingappa, (2000) confidor (Neonicotinoids insecticide) was highly effective against $M$. persicae as compared to acephate and endosulfan. Sayed, et al. (2005) studied the efficacy of different chemical insecticides against $M$. persicae on tobacco crop in Pakistan.

Table 5: The correlation matrix between means of both $M$. persicae and $C$. carnea on potato plants and both daily degrees of temperature and relative humidity showing correlation coefficient values (r) at Beheira Governorate during 2015 and 2016 seasons:

\begin{tabular}{|c|c|c|c|c|c|c|c|}
\hline & & Max. R.H. & Mean R.H. & Min. R.H. & Max. Temp. & Mean Temp. & Min. Temp. \\
\hline \multirow{2}{*}{$\begin{array}{c}M . \\
\text { persicae }\end{array}$} & 2015 & $0.630 * *$ & 0.255 & -0.128 & $0.655 * *$ & $0.779 * *$ & $0.742 * *$ \\
\hline & 2016 & -0.270 & -0.320 & -0.306 & $0.596^{* *}$ & $0.686^{* *}$ & $0.744 * *$ \\
\hline \multirow{2}{*}{ C. carnea } & 2015 & $0.479 * *$ & 0.145 & -0.173 & $0.539 * *$ & $0.697 * *$ & $0.725 * *$ \\
\hline & 2016 & -0.285 & -0.333 & -0.310 & $0.638 * *$ & $0.724 * *$ & $0.774 * *$ \\
\hline
\end{tabular}

Table 6: Efficiency of five insecticides in control of green peach aphid, $M$. persicae population at 1, 4, 7 and 14 days after treatment during 2015 season under field conditions. (mean number of aphids/leaf and \% reduction percentages)

\begin{tabular}{|c|c|c|c|c|c|c|}
\hline \multirow[t]{2}{*}{ Treatments } & \multirow[t]{2}{*}{ Pre spray } & \multicolumn{4}{|c|}{ Post spray (days) } & \multirow[t]{2}{*}{ General mean } \\
\hline & & 1 & 4 & 7 & 14 & \\
\hline Control & $6.28 \pm 0.29$ & $6.73 \pm 0.33$ & $4.93 \pm 0.38$ & $6.1 \pm 0.45$ & $4.7 \pm 0.39$ & \\
\hline Acetamiprid & $6.53 \pm 0.25$ & $\begin{array}{l}1.1 \pm 0.36 \\
(84.34 \pm 4.43)^{\mathbf{b}}\end{array}$ & $\begin{array}{l}0.78 \pm 0.1 \\
(84.85 \pm 2.34)^{\mathrm{a}}\end{array}$ & $\begin{array}{l}0.75 \pm 0.24 \\
(88.33 \pm 2.96)^{\mathrm{a}}\end{array}$ & $\begin{array}{l}1.75 \pm 0.47 \\
(60.7 \pm 12.62)^{\mathrm{a}} \\
\end{array}$ & $(79.55 \pm 3.9)^{\mathrm{a}}$ \\
\hline Thiamethoxam & $7.3 \pm 0.86$ & $\begin{array}{l}0.63 \pm 0.25 \\
(91.95 \pm 3.2)^{\mathrm{a}} \\
\end{array}$ & $\begin{array}{l}0.8 \pm 0.22 \\
(86.01 \pm 3.47)^{\mathrm{a}}\end{array}$ & $\begin{array}{l}1.7 \pm 0.34 \\
(75.86 \pm 4.87)^{b}\end{array}$ & $\begin{array}{l}2.2 \pm 0.56 \\
(59.31 \pm 10.97)^{\mathbf{a b}}\end{array}$ & $(78.28 \pm 4.1)^{\mathrm{a}}$ \\
\hline Chlorantraniliprole & $5.68 \pm 0.4$ & $\begin{array}{l}0.65 \pm 0.21 \\
(89.32 \pm 3.22)^{\mathbf{a b}}\end{array}$ & $\begin{array}{l}0.78 \pm 0.28 \\
(82.77 \pm 5.27)^{\mathrm{a}}\end{array}$ & $\begin{array}{l}1.68 \pm 0.25 \\
(69.37 \pm 5.98)^{\mathbf{b c}}\end{array}$ & $\begin{array}{l}2.35 \pm 0.33 \\
(43.9 \pm 12.59)^{\mathbf{b}}\end{array}$ & $(71.34 \pm 5.8)^{\mathbf{b}}$ \\
\hline Pymetrozine & $6.33 \pm 0.43$ & $\begin{array}{l}0.85 \pm 0.33 \\
(87.43 \pm 4.99)^{\mathbf{a b}}\end{array}$ & $\begin{array}{l}1.4 \pm 0.24 \\
(71.34 \pm 7.42)^{\mathbf{b}}\end{array}$ & $\begin{array}{l}1.88 \pm 0.38 \\
(69.42 \pm 6.15)^{\mathbf{b c}}\end{array}$ & $\begin{array}{l}2.3 \pm 0.45 \\
(51.32 \pm 9.07)^{\mathbf{a b}}\end{array}$ & $(69.88 \pm 4.8)^{\mathbf{b}}$ \\
\hline Pirimicarb & $5.15 \pm 0.62$ & $\begin{array}{l}1.28 \pm 0.17 \\
(76.79 \pm 2.89)^{\mathbf{c}}\end{array}$ & $\begin{array}{l}1.78 \pm 0.13 \\
(55.72 \pm 4.07)^{\mathbf{c}}\end{array}$ & $\begin{array}{l}1.73 \pm 0.2 \\
(65.32 \pm 3.57)^{\mathbf{c}}\end{array}$ & $\begin{array}{l}2.13 \pm 0.24 \\
(44.59 \pm 5.14)^{\mathbf{b}}\end{array}$ & $(60.6 \pm 2.5)^{\mathrm{c}}$ \\
\hline L. S. D. & & $(5.7788)$ & $(7.2897)$ & $(7.3477)$ & $(15.7634)$ & $(6.5688)$ \\
\hline
\end{tabular}

Means followed by the same letter(s) within the same column are nonsignificantly different $(\mathrm{P} \leq 0.05)$ 
Table 7: Efficiency of five insecticides in control of green peach aphid, $M$. persicae population at 1, 4, 7 and 14 days after treatment during 2016 season under field conditions: (mean number of aphids/leaf and \% reduction)

\begin{tabular}{|c|c|c|c|c|c|c|}
\hline \multirow[t]{2}{*}{ Treatments } & \multirow[t]{2}{*}{ Pre spray } & \multicolumn{4}{|c|}{ Post spray (days) } & \multirow[t]{2}{*}{ General mean } \\
\hline & & 1 & 4 & 7 & 14 & \\
\hline Control & $5.33 \pm 0.71$ & $6.25 \pm 0.4$ & $7.1 \pm 0.45$ & $6.25 \pm 0.97$ & $6.83 \pm 0.45$ & \\
\hline Acetamiprid & $6.73 \pm 0.36$ & $\begin{array}{c}0.6 \pm 0.14 \\
(92.42 \pm 1.83)^{\mathrm{a}}\end{array}$ & $\begin{array}{c}1.25 \pm 013 \\
(85.97 \pm 1.89)^{\mathbf{a b}}\end{array}$ & $\begin{array}{c}1.55 \pm 0.21 \\
(81.5 \pm 2.39)^{\mathrm{a}}\end{array}$ & $\begin{array}{c}2.5 \pm 0.29 \\
(71.02 \pm 4.34)^{\mathrm{a}}\end{array}$ & $(82.73 \pm 1.23)^{\mathrm{a}}$ \\
\hline Thiamethoxam & $5.45 \pm 0.39$ & $\begin{array}{c}1.03 \pm 0.15 \\
(83.9 \pm 3.23)^{\mathbf{c}}\end{array}$ & $\begin{array}{c}0.8 \pm 0.14 \\
(89.25 \pm 2.9)^{\mathbf{a}}\end{array}$ & $\begin{array}{c}1.27 \pm 0.25 \\
(80 \pm 3.62)^{\mathrm{a}}\end{array}$ & $\begin{array}{c}1.85 \pm 0.21 \\
(73.67 \pm 1.8)^{\mathrm{a}}\end{array}$ & $(81.7 \pm 1.31)^{\mathrm{a}}$ \\
\hline Chlorantraniliprole & $6.03 \pm 0.94$ & $\begin{array}{c}0.78 \pm 0.21 \\
(88.92 \pm 3.49)^{\mathbf{a b}}\end{array}$ & $\begin{array}{c}1.13 \pm 0.29 \\
(85.99 \pm 2.77)^{\mathbf{a b}}\end{array}$ & $\begin{array}{c}1.8 \pm 0.42 \\
(73.25 \pm 9.79)^{\mathbf{b}}\end{array}$ & $\begin{array}{c}2.78 \pm 0.45 \\
(60.98 \pm 1.83)^{\mathbf{b}}\end{array}$ & $(77.28 \pm 2.06)^{\mathbf{b c}}$ \\
\hline Pymetrozine & $5.48 \pm 0.33$ & $\begin{array}{c}0.9 \pm 0.08 \\
(86 \pm 1.75)^{\mathbf{b}}\end{array}$ & $\begin{array}{c}1.25 \pm 0.25 \\
(82.84 \pm 3.5)^{\mathbf{b}}\end{array}$ & $\begin{array}{c}1.6 \pm 0.29 \\
(74.99 \pm 4.71)^{\mathrm{a}}\end{array}$ & $\begin{array}{c}3.23 \pm 0.22 \\
(53.5 \pm 9.41)^{\mathbf{b}}\end{array}$ & $(74.33 \pm 2.81)^{\mathbf{c}}$ \\
\hline Pirimicarb & $4.8 \pm 0.75$ & $\begin{array}{c}1.08 \pm 0.19 \\
(80.59 \pm 4.77)^{\mathbf{c}}\end{array}$ & $\begin{array}{c}1.83 \pm 0.31 \\
(70.72 \pm 7.68)^{\mathbf{c}}\end{array}$ & $\begin{array}{c}2.15 \pm 0.21 \\
(61.44 \pm 3.34)^{\mathbf{c}}\end{array}$ & $\begin{array}{c}2.78 \pm 0.6 \\
(54.95 \pm 7.88)^{\mathbf{b}}\end{array}$ & $(66.93 \pm 2.62)^{\mathbf{d}}$ \\
\hline L. S. D. & & $(4.8568)$ & $(6.3903)$ & $(8.2065)$ & $(8.9403)$ & $(3.1766)$ \\
\hline
\end{tabular}

Means followed by the same letter(s) within the same column are nonsignificantly different $(P \leq 0.05)$

They found that the lowest mean numbers of aphid/leaf was recorded with confidor and actara treated plots, while highest mean numbers of aphids per leaf was recorded with methomyl and tracer. In the laboratory, Gavkare, et al., (2013) evaluated the relative toxicity of some insecticides viz., acetamiprid, fipronil, imidacloprid, lambda cyhalothrin, malathion and thiamethoxam to apterous adults of $M$. persicae using leaf dipping method of bioassay. They found that thiamethoxam was the highest toxic insecticide, followed by imidacloprid and Malathion. Therefore, our chemical control results agree with the above mentioned results.

Side effect of the tested insecticides on the larvae of green lace-wing $C$. carnea, is shown in Tables (8-9). Data indicated that, mean of reduction percentages of the larvae of $C$. carnea /10 potato plants at the four investigation times were 58.13,
52.84, 47.99, 45.96 and $44.54 \%$ for chlorantraniliprole, Pirimicarb, thiamethoxam, acetamiprid and pymetrozine treatments, respectively during 2015 season. They were 58.55 , $54.11,45.76,43.74$, and 42.62 insect, respectively during 2016 season. Data clarified that, all treatments have moderate toxic effects on C. carnea except acetamiprid, chlorantraniliprole and pirimicarb which have a high toxic effect. The present results agree with those of Barrania and Abou-Taleb, (2014) who tested six insecticides viz., pyriproxyfen, novaluron, thiamethoxam, imidacloprid, acetamiprid and chlorantraniliprole against Bemisia tabaci, Aphis gossypii and their associated predators in cotton fields. They found that all treatments have moderate toxic effects on the natural enemy Chrysopa vulgaris especially pyriproxyfen and acetamiprid.

Table 8: Harmful effect of five insecticides on $C$. carnea population at 1, 4, 7 and 14 days after treatment during 2015 season under field conditions:

\begin{tabular}{|c|c|c|c|c|c|c|}
\hline \multirow[t]{2}{*}{ Treatments } & \multirow[t]{2}{*}{ Pre spray } & \multicolumn{4}{|c|}{$\begin{array}{l}\text { Mean No. of insects/plant and \% reduction } \\
\text { Post spray (Days) }\end{array}$} & \multirow[t]{2}{*}{ General mean } \\
\hline & & 1 & 4 & 7 & 14 & \\
\hline Control & $4.83 \pm 0.66$ & $5.08 \pm 0.92$ & $5.5 \pm 0.54$ & $4.98 \pm 0.49$ & $4.05 \pm 0.39$ & \\
\hline Chlorantraniliprole & $4.65 \pm 0.7$ & $\begin{array}{l}2.05 \pm 0.34 \\
(56.39 \pm 13.16)^{\mathrm{a}}\end{array}$ & $\begin{array}{l}1.5 \pm 0.18 \\
(71.69 \pm 5.88)^{\mathrm{a}}\end{array}$ & $\begin{array}{l}1.35 \pm 0.29 \\
(72.02 \pm 3.1)^{\mathrm{a}}\end{array}$ & $\begin{array}{l}2.6 \pm 0.22 \\
(32.42 \pm 11.77)^{\mathrm{a}}\end{array}$ & $(58.13 \pm 7.16)^{\mathrm{a}}$ \\
\hline Pirimicarb & $4.33 \pm 1.1$ & $\begin{array}{l}1.73 \pm 0.13 \\
(58.65 \pm 14.3)^{\mathbf{a}}\end{array}$ & $\begin{array}{l}1.8 \pm 0.34 \\
(62.87 \pm 6.59)^{\mathbf{b}}\end{array}$ & $\begin{array}{l}1.73 \pm 0.39 \\
(60.7 \pm 8.09)^{\mathbf{a b}}\end{array}$ & $\begin{array}{l}2.55 \pm 0.42 \\
(29.15 \pm 11.24)^{\mathrm{a}}\end{array}$ & $(52.84 \pm 8.89)^{\mathbf{a b}}$ \\
\hline Thiamethoxam & $5.18 \pm 0.38$ & $\begin{array}{l}2.08 \pm 0.26 \\
(59.71 \pm 14.87)^{\mathrm{a}}\end{array}$ & $\begin{array}{l}2.28 \pm 0.17 \\
(61.26 \pm 5.46)^{\mathbf{b}}\end{array}$ & $\begin{array}{l}2.68 \pm 0.21 \\
(48.81 \pm 14.1)^{\mathbf{b c}}\end{array}$ & $\begin{array}{l}2.35 \pm 0.37 \\
(22.19 \pm 14.58)^{\mathrm{a}}\end{array}$ & $(47.99 \pm 10.48)^{\mathrm{ab}}$ \\
\hline Acetamiprid & $5.08 \pm 0.38$ & $\begin{array}{l}2.8 \pm 0.68 \\
(47.77 \pm 7.47)^{\mathbf{a}} \\
\end{array}$ & $\begin{array}{l}2.5 \pm 0.24 \\
(56.97 \pm 2.18)^{\mathbf{b}}\end{array}$ & $\begin{array}{l}2.4 \pm 0.54 \\
(54.42 \pm 8.96)^{\mathbf{b c}}\end{array}$ & $\begin{array}{l}3.23 \pm 0.4 \\
(24.69 \pm 5.68)^{\mathbf{a}}\end{array}$ & $(45.96 \pm 2.71)^{\mathbf{a b}}$ \\
\hline Pymetrozine & $4.3 \pm 0.64$ & $\begin{array}{l}2.25 \pm 0.25 \\
(48.21 \pm 15.93)^{\mathrm{a}}\end{array}$ & $\begin{array}{l}1.9 \pm 0.29 \\
(61.42 \pm 1.38)^{\mathbf{b}}\end{array}$ & $\begin{array}{l}2.45 \pm 0.21 \\
(44.6 \pm 4.73)^{\mathbf{c}}\end{array}$ & $\begin{array}{l}2.72 \pm 0.19 \\
(23.95 \pm 8.96)^{\mathbf{a}}\end{array}$ & $(44.54 \pm 5.41)^{\mathbf{b}}$ \\
\hline L. S. D. & & $(20.382)$ & $(7.2112)$ & $(12.8277)$ & $(16.3469)$ & $(11.2151)$ \\
\hline
\end{tabular}

Means followed by the same letter(s) within the same column are nonsignificantly different $(P \leq 0.05)$ 
Table 9: Harmful effect of four insecticides on $C$. carnea population at 1, 4, 7 and 14 day after treatment during 2016 season under field conditions:

\begin{tabular}{|c|c|c|c|c|c|c|}
\hline \multirow[t]{2}{*}{ Treatments } & \multirow{2}{*}{$\begin{array}{c}\text { Pre } \\
\text { spray }\end{array}$} & \multicolumn{4}{|c|}{ Mean No. of insects/plant and \% reduction Post spray (Days) } & \multirow[t]{2}{*}{ General mean } \\
\hline & & 1 & 4 & 7 & 14 & \\
\hline Control & $5.08 \pm 0.76$ & $5.57 \pm 0.34$ & $5.38 \pm 0.74$ & $4.97 \pm 0.17$ & $4.55 \pm 0.91$ & \\
\hline Chlorantraniliprole & $5.25 \pm 0.73$ & $\begin{array}{l}1.38 \pm 0.26 \\
(75.99 \pm 5.55)^{\mathrm{a}}\end{array}$ & $\begin{array}{l}2 \pm 0.57 \\
(63.21 \pm 13.41)^{\mathbf{a b}}\end{array}$ & $\begin{array}{l}2.53 \pm 0.64 \\
(51.2 \pm 10.29)^{\mathrm{a}} \\
\end{array}$ & $\begin{array}{l}2.8 \pm 0.39 \\
(43.81 \pm 6.15)^{\mathbf{a}} \\
\end{array}$ & $(58.55 \pm 6.48)^{\mathrm{a}}$ \\
\hline Pirimicarb & $4.7 \pm 0.45$ & $\begin{array}{l}1.55 \pm 0.26 \\
(69.29 \pm 9.94)^{\mathbf{a b}}\end{array}$ & $\begin{array}{l}1.55 \pm 0.26 \\
(68.47 \pm 5.88)^{\mathrm{a}}\end{array}$ & $\begin{array}{l}2.48 \pm 0.43 \\
(45.53 \pm 15.57)^{\mathrm{a}}\end{array}$ & $\begin{array}{l}2.78 \pm 0.29 \\
(33.14 \pm 11.21)^{\mathbf{a b}}\end{array}$ & $(54.11 \pm 10.1)^{\mathbf{a b}}$ \\
\hline Thiamethoxam & $4.48 \pm 0.33$ & $\begin{array}{l}1.65 \pm 0.17 \\
(66.49 \pm 4.91)^{\mathbf{a b}}\end{array}$ & $\begin{array}{l}2.3 \pm 0.43 \\
(50.83 \pm 12.38)^{\mathbf{b}}\end{array}$ & $\begin{array}{l}2.63 \pm 0.41 \\
(40.9 \pm 5.17)^{\mathrm{a}} \\
\end{array}$ & $\begin{array}{l}3 \pm 0.47 \\
(24.81 \pm 10.72)^{\mathbf{b}}\end{array}$ & $(45.76 \pm 6.35)^{\mathbf{b}}$ \\
\hline Acetamiprid & $4.95 \pm 0.65$ & $\begin{array}{l}2.18 \pm 0.13 \\
(59.04 \pm 10.73)^{\mathbf{b}}\end{array}$ & $\begin{array}{l}2.35 \pm 0.38 \\
(55.38 \pm 2.58)^{\mathbf{a b}}\end{array}$ & $\begin{array}{l}3.05 \pm 0.45 \\
(35.1 \pm 12.14)^{\mathrm{a}} \\
\end{array}$ & $\begin{array}{l}3.33 \pm 0.51 \\
(25.43 \pm 16.67)^{\mathbf{b}}\end{array}$ & $(43.74 \pm 7.77)^{\mathbf{b}}$ \\
\hline Pymetrozine & $5.08 \pm 0.25$ & $\begin{array}{l}2.7 \pm 0.22 \\
(45.89 \pm 2.42)^{\mathbf{c}} \\
\end{array}$ & $\begin{array}{l}2.47 \pm 0.22 \\
(55.2 \pm 2.33)^{\mathbf{a b}}\end{array}$ & $\begin{array}{l}2.93 \pm 0.21 \\
(44.1 \pm 12.13)^{\mathrm{a}}\end{array}$ & $\begin{array}{l}3.48 \pm 0.32 \\
(25.3 \pm 7.64)^{\mathbf{b}}\end{array}$ & $(42.62 \pm 3.69)^{\mathrm{c}}$ \\
\hline L. S. D. & & $(11.5964)$ & $(14.1544)$ & $(17.4896)$ & $(16.7568)$ & $(11.18)$ \\
\hline
\end{tabular}

Means followed by the same letter(s) within the same column are nonsignificantly different $(\mathrm{P} \leq 0.05)$

\section{REFERENCES}

Abd El-Hameed Neama A., Afaf Abd El-Wahab, Horia A. Abd El-Wahab and Marwa M. Mousa (2016): Efficiency of Chrysoperla carnea (Stephens) to suppress Myzus persicae (Sulzer) infesting potato plants in the field. Current Science International, 5(3): 325-327.

Abdel - Meguid, M.A. and A.M. Amin (1994): Heat accumulation for timing pink bollworm Pectinophora gossypiella (Saund.) control measures in Monoufia Governorate cotton complex. Egypt. J. Appl. Sci., 9 (11): 71 - 78.

Al-Beltagy, A.M. (1999): Heat unit's accumulations for forecasting spiny bollworm, Earias insulana (Boisd.), population dynamics and density on cotton. The 2nd Int. Conf. of Pest Control, Mansoura, Egypt, 737-744.

Alomairini, A.S. (2004): Entomofauna of pepper plants and the effect of Plant variety on biology and morphology of aphids. M.Sc. Thesis, College of Food and Agriculture Sciences, King Saud University, 94 pp.

Asin, L. and X. Pons, (2001): Effect of high temperature on the growth and reproduction of corn aphids (Homoptera: Aphididae) and implications for their population dynamics on the northeastern Iberian peninsula. Environmental Entomology, 30:1127-1134.

Barrania1 A. A. and H. K. Abou-Taleb (2014): Field efficiency of some insecticide treatments against whitefly, Bemisia tabaci, cotton aphid, Aphis gossypii and their associated predator, Chrysopa vulgaris, in cotton plants. Alex. J. Agric. Res. 59 (2): 105-111

Chakravarty, N.V.K. and R.D. Gautam, (2004): Degree-day based forewarning system for mustard aphid. Journal of Agrometeorology, 6:215-222.
Chattopadhyay, C.; R. Agrawal; A. Kumar; Y.P. Singh; S.K. Roy; S.A. Khan; L.M. Bhar; N.V.K. Chakravarthy; A. Srivastava; B.S. Patel; B. Srivastava; C.P. Singh and S.C. Mehta (2005): Forecasting of Lipaphis erysimi on oilseed Brassicas in India - a case study. Crop Protection, 24:1042-1053.

Chu, C.C. and T.J. Henneberry (1990): Pectinophora gossypiella (Saund.) population dynamics, pheromone traps, sex pheromone and fields Gossypium hirsutum.California, Proc. Beltwide Cotton Prod. Res. Conf., Memphis Tenn., 184 - 185.

Cividanes F.J. and V.P. Souza (2003): Exigências térmicas e tabelas de vida de fertilidade de Myzus persicae (Sulzer) (Hemiptera: Aphididae) em laboratório. Neotropical Entomology, 32:413-419.

Cividanes F.J. and T.M.d. Santos-Cividanes (2012): Predicting the occurrence of alate aphids in Brassicaceae. Pesq. agropec. bras., Brasília, 47(4):505-510.

Dahi, H. F. (2003): Predicting the annual generations of the spiny bollworm Earias insulana (Boisd.) (Lepidoptera: Archtidae). Ph. D. Thesis, Fac. Agric., Cairo Univ., 182 pp.

Dahi, H. F. (2007): Using Heat Accumulation and Sex Pheromone Catches to Predicate the American Bollworm Helicoverpa armigera Hub. field Generations.J. Agric. Sci. Mansoura Univ., 32 (4): 3037-3044.

Dixon, A.F.G. (1998): Aphid ecology: an optimization approach. 2nd ed. London: Chapman and Hall, 300pp.

El-mezayyen, G.A. and M.G. Ragab (2014): Predicting the American boll worm, Helicoverpa armigera (Hubner) Field Generations as influenced by heat unit accumulation. Egypt. J. Agric. Res., 92 (1): 9199. 
Francis, F.; P. Gerkens; N. Harmel; G. Mazzucchelli; E. Pauw and E. Haubruge (2006): Proteomics in Myzus persicae: effect of aphid host plant switch. Insect Biochemistry and Molecular Biology, 36:219-227.

Fericean L.M.; I. Palagesiu; R. Palicica; A.M. Varteiu and S. Prunar (2011): The behavior, life cycle and biometrical measurements of Myzus persicae. Research Journal of Agricultural Science, 43 (1): 34-39.

Fujiwara, C. and M. Nomura (1999): Effects of photoperiod and temperature on larval development of Chrysoperla carnea Stephens (Neuroptera: Chrysopidae). Japanese Journal of Applied Entomology and Zoology, 43(4), 175179.

Gavkare O.; S. Kumar; N. Sharma and P. L. Sharma (2013): Evaluation of some novel insecticides against Myzus persicae (Sulzer). The Bioscan, 8(3): 1119-1121

Gomez, N.N.; R.C. Venette; J.R. Gould and D.F. Winograd (2009): A unified degree day model describes survivorship of Copitarsia corruda Pogue \& Simmons (Lepidoptera: Noctuidae) at different constant temperatures. Bulletin of Entomological Research, 99:65-72.

Hanula, J.L.; G.L. Debarr; J.C. Weatherby; L.R. Barber and C.W. Berisford (2002): Degree-day model for timing insecticide applications to control Dioryctria amatella (Lepidoptera: Pyralidae) in loblolly pine seed orchards. The Canadian Entomologist, 134:255-268.

Henn, T. and R. Weinzier (1990): Alternatives in insect pest management. Beneficial insects and mites. University of Illinois, Circular 1298:24.

Henderson C. and E. Tilton (1955): Tests with acaricides against the brown wheat mite. Journal of Economic Entomology, 48:157-161.

Klueken, A.M.; B. Hau; B. Uler and H.M. Poehling (2009): Forecasting migration of cereal aphids (Hemiptera: Aphididae) in autumn and spring. Journal of Applied Entomology, 133: 328-344.

Mdellel, L. and M. Ben Halima Kamel (2014): Effects of different varieties of pepper on the biological parameters of the green peach aphid Myzus persicae Sulzer (Hemiptera, Aphididae) in Tunisia. European Journal of Environmental Sciences. 4(2): 102-105

Palumbo, J.C.; R. Horowitz and N. Prabhaker (2001): Overview of insecticidal control and resistance management for Bemisia tabaci. Crop Prot. 20: 739-765.

Patil, C.S. and S. Lingappa (2000): Selective toxicity of some insecticides against tobacco aphid, Myzus nicotianae Blackman and its predator, Cheilomenes sexmaculata (Fabricius). J. biol. Cont., 14: 41-44.
Raman K.V. and D.J. Midmore (1983): Efficacy of insecticides against major insect pests of potatoes in hot climates of Peru. Journal of Crop Protection; 2(4):483-489.

Ro, T.H.; Garrell E. Long and H.H. Toba (1998): Predicting phenology of green peach aphid (Homoptera: Aphididae) using Degree-Days. Environ Entomol. 27(2):337-343.

Richmond, J. A.; H. A. Thomas and H. B. Hattachargya (1983): Predicting spring flight of Nantucket pine tip moth (Lepidoptera: Olethreutidae) by heat unit accumulation. J. Econ. Entomol., 76: 269-271.

Rosenhein, J.A. and L.R. Nilhoit (1993): Predators that eat other predators disrupt cotton aphid control. Cal. Agricul, 47:7-9.

Saljoqi A.R. (2009): Population dynamics of Myzus persicae and its associated natural enemies in spring potato crop, Peshawar-Pakistan. Sarhad Journal of Agriculture; 25:452-456.

Salman, A.M.A; A.O. Abd El-latif; S.F.M. Moussa and M.M.S. Bakry (2016): Estimation of the annual field generations of Parlatoria blanchardii and prediction of its expected peaks using thermal units accumulation under Luxor governorate condition, Egypt. Journal of Sohag Agri-Science (JSAS), 1(1): 9-25.

SAS Institute, Inc. (1999): PC—SAS users guide, Version 8. North Carolina statistical analysis system Institute, Inc.

Sayed F.; M. Sajjad Khan; M. Hamayoon Khan and Hayat Badshah (2005): Efficacy of different insecticides against aphid Myzus persicae L. on tobacco crop. Pakistan J. Zool., 37(3):193-197.

Silveira Neto, S.; O. Nakano; D. Barbin; N. A. Villa Nova (1976): Manual de ecologia dos insetos. São Paulo: Ceres, 419p.

Steel, J. F. and J. H. Torrie (1960): Principles and Procedures of statistics. McCraw-Hill, New York.

Tabikha, R. M. M. (2016): Impacts of Temporal and Spatial Climatic Changes on Annual Generations of Rhopalosiphum maidis and $R$. padi (Hemiptera: Aphididae) in Egypt, Using Geographical Information System (GIS). Journal of Agricultural Informatics 7(1): 13-22.

Tang, Y.Q.; S.L. Lapinte; L.G. Brown and W.B. Hunter (1999): Effects of host plant and temperature on the biology of Toxoptera citricida (Homoptera: Aphididae). nvironmental Entomology, 28:895-900.

Tomizawa M.; D. Maltby, K.F. Medzihradszky; N. Zhang; K.A. Durkin; J. Presly; T.T. Talley; P. Taylor; A.L. Burlingame and J.E. Casida (2007): Defining nicotinic agonist binding surfaces through photo affinity labeling. Biochemistry 46: 8798-8806. 
Western Regional IPM Project (US), University of California Integrated Pest Management Program (2006): Integrated Pest Management for potatoes in the Western United States. 2nd edition. ANR Publishers. USA.

Yones, M.S.; H.F. Dahi; H.A. Abdel Rahman; A.F. Abou Hadid and S.M. Arafat (2012): Using Remote Sensing Technologies and Sex Pheromone Traps for Prediction of the Pink Bollworm, Pectinophora gossypiella (Saund.), Annual Field Generations. Nature and Science; 10 (7) 6-10.
Zamani, A.A.; A.A. Talei; Y. Fathipour and V. Baniameri (2006): Effect of temperature on biology and population growth parameters of Aphis gossypii Glover (Hom., Aphididae) on greenhouse cucumber. Journal of Applied Entomology, 130:453-460.

\title{
المالهص العري
}

\section{التنبؤبالأجيل الجقلية لهشرةمن الخوخ الأخضر Myzus persicae (Sulzer) ومفترسها هشرة أسد المن Chrysoperla carnea (Stephens) بلسيتخدلم الوحدات الحراربة الترلممية وقيم بهض المبيدلت ضد عشائرهم}

\author{
عنلن عبدالفتاح اللسيد روضش،محمدمبروك رجب علية \\ قنم وقاية النبل - كلية الزراعة جلمعة دمنهور - جمهورية مصر العربية
}

التنبؤ الحقلي بمجلمبع الهشرات ضروري لتققيق نتائج مرضية في برامج المكلفحة المتكلملة. تتهف هذه

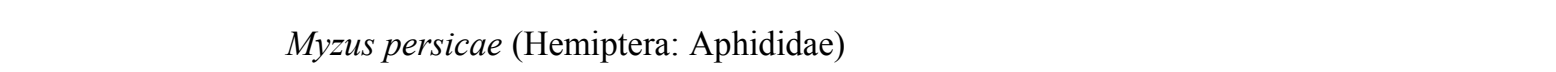
وكذلك نقدير تأثير الحرارة والرطوبة علي الكثافة العددية Chrysoperla carnea (Neuroptera: Chrysopidae)

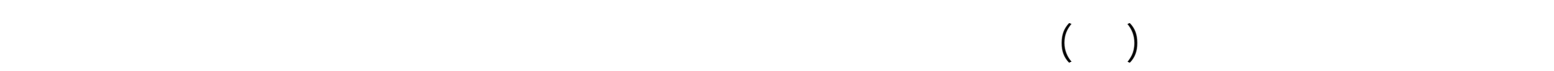

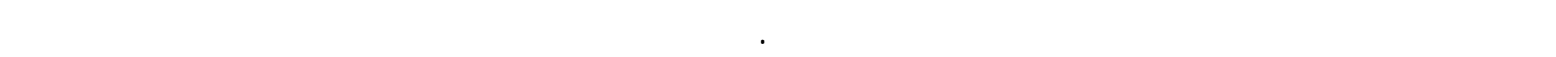

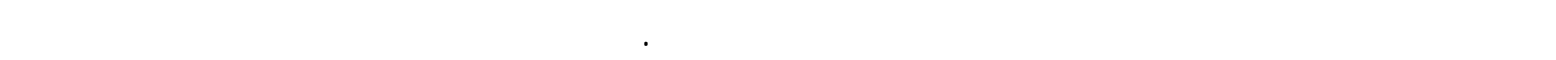

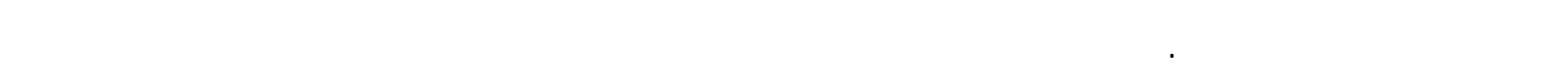

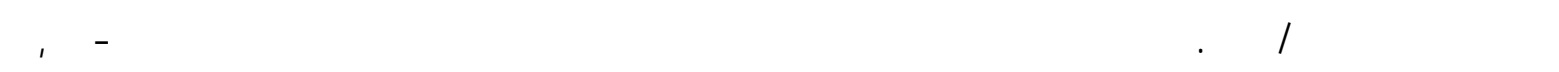

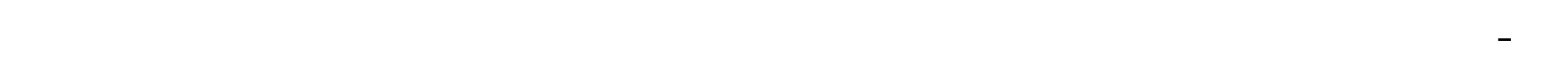

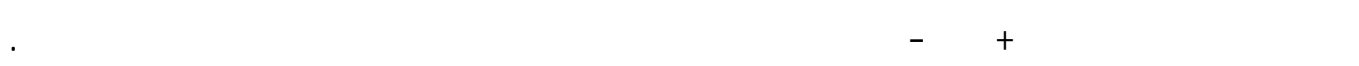

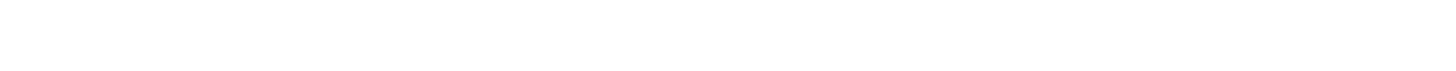
ارتبط معنوية موجبة (طررية) بين تعداد الهثرتين والمتونط اليومي لدرجلت الحرارة الدنيا والمتوططه والعليا.

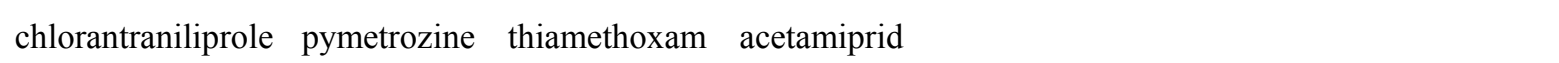
و pirimicarb علي الكثافة العددية للمشرتين. وكان ترتيب هذه المبيدات تنازليا مسب كفاعتها علي مشرة من الخوخ

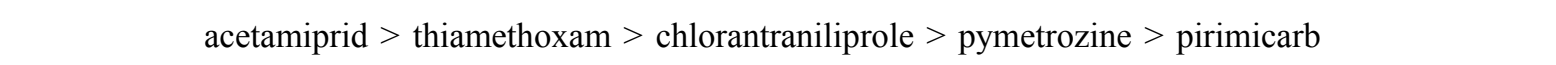

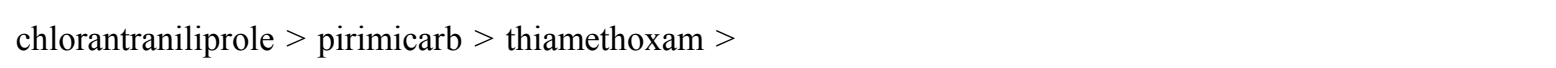
1 acetamiprid > pymetrozine 